\title{
Education Standards and Competence-oriented Curricula - The Austrian Technical Colleges Take a New Approach to Excellence
}

\author{
An Overview of the Austrian Education System and of the Importance of the Higher- \\ Level Vocational Schools (VET Colleges) \\ http://dx.doi.org/ijep.v1i3.1818
}

W. Pachatz, A. Zafoschnig

Ministry of Education, the Arts and Culture, Vienna, Austria

\begin{abstract}
In Austria, Technical Colleges are those educational institutions that train and educate the skilled technical staff required by the Austrian labour market and the universities. These colleges have contributed a lot to Austria's economic success and every year about 8,000 young engineers leave the technical schools to form a powerful work and study force.
\end{abstract}

Therefore, it is particularly important that the education they receive meets the requirements of prospective employers and that innovative developments are anticipated. As a consequence, the Austrian Technical Colleges have developed curricula that rely on learning outcomes and competence-based results. This new orientation towards skills, knowledge and competences shall be achieved through learning objectives that precisely describe the education chosen. How these standards have been designed, matched with the curricula, and implemented at the Colleges will be described in this paper.

Index Terms-Austrian Technical Colleges, competenceoriented curricula, education standards, EQF, HTL, learning outcomes .

\section{INTRODUCTION}

In Austria, Vocational Education and Training have always a traditionally strong role. This may be seen from the fact that in secondary education not only the Vocational Schools for Apprentices, but even more so the Secondary Technical and Vocational Colleges attract students from the age group $14-19$. These colleges offer either 4-year courses that help to develop the technical and industrial skills of young people, as well as their professional aptitude for arts and crafts, or 5-year courses that provide them with higher technical, industrial and arts \& crafts qualifications.

The significance of the fully school-based vocational education becomes clear when looking at the popular demand that these schools exercise for young Austrians. Nearly $80 \%$ of the 15 -year olds opt for a vocational education institution whereas the remaining $20 \%$ choose a general education school. Within the VET sector, half of the 15-year olds decide to attend a Vocational School for Apprentices and thus become part of the dual system that offers a mixture of company-based and school-based education. The other $50 \%$ of the students enrol at the Higher Vocational Education Colleges, whereby again half of those in turn attend the 5-year schools offering higher technical, industrial and arts \& crafts qualifications, the so-called HTL [1].

At present, the Austrian technical colleges train and educate more than 60,000 students altogether. Every year approximately 8,700 young engineers leave the technical schools to form a powerful work and study force [2]. Since the beginning of the 90ies, the number of graduates has increased by approximately 30\%. Those graduates who immediately enter the working process amount to approximately 60 - 70\%. The percentage of persons active in the world of work has thus increased from $2.4 \%$ (1991) to 3.8\% (2006). This clearly shows which high importance the VET colleges have in providing the labour market with skilled workers, especially since graduates from these institutions do not at all run a high risk of unemployment [3].

The above-mentioned HTL-education also has a great impact on the tertiary sector, because $53 \%$ of all young people beginning their studies of the "Engineering Sciences" at Austrian universities in 2005/06 graduated from a Technical VET College beforehand. This percentage was even higher at the Universities of Applied Sciences, namely $73 \%$ [4]. These statistic figures show clearly that the higher education providers in the tertiary sector recruit more than half of their students for their „Technology" and "Engineering Sciences" programmes from the Technical Colleges.

Considering the lengths of the various study programmes and the immediate availability of their graduates for the labour market, the following comparison shows favourable results for employing a graduate of an HTL:

TABLE I.

COMPARISON OF DIFFERENT EDUCATION PROGRAMMES

\begin{tabular}{|c|c|c|}
\hline Education programme & $\begin{array}{c}\text { Length of } \\
\text { study/duration of } \\
\text { courses1 }\end{array}$ & Age of graduates \\
\hline HTL & 5 years & 19 to 20 years of age \\
\hline $\begin{array}{c}\text { Diploma studies: } \\
\text { Electrical Engineering } \\
\text { (University) }\end{array}$ & 16,5 semesters & 26 to 29 years of age \\
\hline $\begin{array}{c}\text { FH Diploma studies } \\
\text { (Uni for Applied Sci- } \\
\text { ences) }\end{array}$ & $8-10$ semesters & 23 to 25 years of age \\
\hline \multicolumn{2}{|c}{}
\end{tabular}


Another special feature of the Technical Colleges is that they enable their graduates to apply for the professional title of „Ingenieur / Registered Engineer“ after three (3) years of qualified work practice. Consequently, the Federal Ministry of Economy, Family and Youth regularly receives between 3500 and 4000 applications for the above title (these are about $50 \%$ of all the graduates coming from one annual HTL graduation cycle). In the sector of academic studies, 2348 graduates [6] completed their studies at a University of Applied Science ("Engineering Sciences”, „Technology“) in

2005/06, at roughly the same time, in 2004/05 [7], the Technical Universities ("Engineering studies", "Production and Manufacturing" and "Building Construction”) produced 1803 graduates in the technical field.

From this comparison between the various education institutions it may be seen that, firstly, the number of technically qualified graduates from the Austrian VET Colleges and, secondly, also their earlier availability for prospective employers and for the labour market, are very strong assets that put the "HTL engineers" on top of the pyramid of potential candidates for leading and managing positions in the technical and industrial sectors. This has also been confirmed by corresponding feedback from the Austrian technical enterprises who confirm that the Technical Colleges are the main providers of qualified male and female personnel for their needs.

When one attempts to analyse respective job advertisements in the media, it becomes apparent that employers very frequently ask for HTL and FH graduates (72\%) or for HTL and university graduates (54\%) to fill the job vacancies in the technical sector [8]. These findings show that the labour market needs in the technical field can best be matched by graduates from both the tertiary education sector as well as by graduates from the Higher Technical Colleges, which proves the high quality of the education and training provided at the Austrian HTL.

\section{Copenhagen PROCEss AND EQF}

In connection with the aspects of job flexibility and mobility, the Lisbon-Agenda by the EU formulated the following objectives in the year 2000.

By 2010 the European Union should have become the most competitive and dynamic, and knowledge-based economic area in the world. According to the Declaration of Bologna, this means the creation of a European tertiary area; but in the vocational area the Copenhagen-process has put these objectives into realisation. Those two processes should guarantee transparency and mobility as well as acknowledgement and recognition in education. Another important aim is to make professional qualifications comparable and transparent on the European level. The instruments that were created to guarantee these criteria were as follows:

\section{A. European Qualifications Framework (EQF)}

The European Qualifications Framework (EQF) is an instrument of reference that is used across the European Union to compare and to acknowledge the national qualifications of the various member states. The EQF is concerned with general education, but also with vocational education and training, and with higher education. The 8 levels of reference comprise all qualifications, beginning with elementary school and reaching up to qualifications which can be acquired at the highest level of academic and professional education and further education. All the important skills, elements of knowledge, and competences, are described therein, irrespective of where and how these qualifications were acquired. The EQF does not compare qualifications from the point of view of learning paths and learning content, but from the point of view of learning outcomes and learning results. Consequently, the European Union member states have also developed their own national qualifications frameworks. By 2012, all newly issued diploma, certificates and Europass-documents shall contain the necessary information in relation to the relevant EQF Levels.

\section{B. National Qualifications Framework (NQF)}

The NQF consists of a different number of levels in the various member states. They do, however, correspond to defined national learning levels. The NQF reflects the national qualifications system and the levels that the various institutions represent. This system will then be transferred to the European Qualifications Framework, so that the qualification of one member state can be compared with the qualification of another. The legibility and the acknowledgement of qualifications will thus be simplified in all the member states.

\section{Brugge Communiqué 2010}

To revive the Copenhagen-Process, the Council of Europe has determined the following rules within the framework of the Brugge Communiqué:

By 2020, vocational education and training in Europe shall have become more attractive, more relevant, more focused on individual careers, more innovative, better accessible and more flexible, than in the year 2010. It should also contribute to high achievements and to fairness in lifelong learning by offering the following elements of education (excerpts):

- "Professional and vocational education shall be considered as an attractive alternative to general education. VET systems shall teach the learners basic competences and concrete professional skills;

- Flexible systems of professional educations that are based on a concept which focuses on learning outcomes and learning results.

- A common European area for general and vocational education with transparent qualification systems that allow the transition, interlocking and permeability of learning results, as well as the recognition of qualifications and competences leading to a mobility across borders;"

The aim of the European Union to become the most competitive and most dynamic knowledge-based economic area in the world cannot be achieved without efficient and effective educations systems. In this process, vocational education and training systems have a particular significance. Not only in Austria, the EQF will act as a translation device to make national qualifications better understandable across Europe. This will promote the worker's and learner's mobility between the member states and will lead to a better acceptance of the national qualifications of employees across Europe. 
TABLE II.

DESCRIPTORS DEFINING LEVELS IN THE EUROPEAN QUALIFICATIONS FRAMEWORK (EQF), EXCERPT [9]

\begin{tabular}{|c|c|c|c|}
\hline Knowledge & \multicolumn{2}{|c|}{ Skills } & Competence \\
\hline $\begin{array}{l}\text { In the context of EQF, knowledge } \\
\text { is described as theoretical and/or } \\
\text { factual. }\end{array}$ & \multicolumn{2}{|c|}{$\begin{array}{l}\text { In the context of EQF, skills are described as cognitive (involving } \\
\text { the use of logical, intuitive and creative thinking) and practical } \\
\text { (involving manual dexterity and the use of methods, materials, } \\
\text { tools and instruments). }\end{array}$} & $\begin{array}{l}\text { In the context of EQF, competence } \\
\text { is described in terms of responsibil- } \\
\text { ity } \\
\text { and autonomy. }\end{array}$ \\
\hline $\begin{array}{c}\text { Level } 3 \\
\text { The learning outcomes relevant } \\
\text { to Level } 3 \text { are }\end{array}$ & $\begin{array}{l}\text { knowledge of facts, principles, } \\
\text { processes and general concepts, } \\
\text { in a field of work or study }\end{array}$ & $\begin{array}{l}\text { a range of cognitive and practi- } \\
\text { cal skills required to accom- } \\
\text { plish tasks and solve problems } \\
\text { by selecting and applying basic } \\
\text { methods, tools, materials and } \\
\text { information }\end{array}$ & $\begin{array}{l}\text { take responsibility for completion } \\
\text { of tasks in work or study, adapt own } \\
\text { behaviour to circumstances in } \\
\text { solving problems }\end{array}$ \\
\hline $\begin{array}{l}\text { Level } 4 \\
\text { The learning outcomes } \\
\text { relevant to Level } 4 \text { are }\end{array}$ & $\begin{array}{l}\text { factual and theoretical knowl- } \\
\text { edge in broad contexts within a } \\
\text { field of work or study }\end{array}$ & $\begin{array}{l}\text { a range of cognitive and practi- } \\
\text { cal skills required to generate } \\
\text { solutions to specific problems } \\
\text { in a field of work or study }\end{array}$ & $\begin{array}{l}\text { exercise self-management within } \\
\text { the guidelines of work or study } \\
\text { contexts } \\
\text { that are usually predictable, but are } \\
\text { subject to change } \\
\text { supervise the routine work of } \\
\text { others, taking some responsibility } \\
\text { for the evaluation and improvement } \\
\text { of work or study activities }\end{array}$ \\
\hline $\begin{array}{l}\text { Level } 5 \\
\text { The learning outcomes relevant } \\
\text { to Level } 5 \text { are }\end{array}$ & $\begin{array}{l}\text { comprehensive, specialised, } \\
\text { factual and theoretical knowl- } \\
\text { edge within a field of work or } \\
\text { study and an awareness of the } \\
\text { boundaries of that knowledge }\end{array}$ & $\begin{array}{l}\text { a comprehensive range of } \\
\text { cognitive and practical skills } \\
\text { required to develop } \\
\text { creative solutions to abstract } \\
\text { problems }\end{array}$ & $\begin{array}{l}\text { exercise management and supervi- } \\
\text { sion in contexts of work or study } \\
\text { activities where there is unpredict- } \\
\text { able change, review and develop } \\
\text { performance of self and others }\end{array}$ \\
\hline $\begin{array}{l}\text { Austrian NQF Qualifications } \\
\text { integrated in EQF Level } 6 \text { The } \\
\text { learning outcomes relevant to } \\
\text { Level } 6 \text { are }\end{array}$ & $\begin{array}{l}\text { advanced knowledge of a field } \\
\text { of work or study, involving a } \\
\text { critical } \\
\text { understanding of theories and } \\
\text { principles }\end{array}$ & $\begin{array}{l}\text { advanced skills, demonstrating } \\
\text { mastery and innovation, re- } \\
\text { quired to solve complex and } \\
\text { unpredictable problems in a } \\
\text { specialised field of } \\
\text { work or study }\end{array}$ & $\begin{array}{l}\text { manage complex technical or } \\
\text { professional activities or projects, } \\
\text { taking responsibility for decision- } \\
\text { making in unpredictable work or } \\
\text { study contexts, take responsibility } \\
\text { for managing professional devel- } \\
\text { opment of individuals and groups }\end{array}$ \\
\hline
\end{tabular}

From a national point of view, it is thus particularly important to relate the Austrian National Qualifications System to the EQF so as to guarantee that the levels of the national qualifications will be placed at the right European reference levels. For the first time, the focus will shift from emphasising learning inputs to describing what a learner knows, understands, and is able to do, that is to say, to learning outcomes. Such a concept also encourages lifelong learning by promoting the inclusion of qualifications that were acquired through non-formal and informal learning.

In Austria, the classification and validation of learning outcomes is determined by the National Qualifications Framework, whose 8 levels correspond to the ones of the EQF. For such a classification it is inevitable to provide possibilities for a comparison of the competences and skills taught in order to meet the requirements of the logic of the two qualifications frameworks.

\section{LEARNING OUTCOME ORIENTATION - EDUCATION STANDARDS}

The acceptance of the EQF as a translation device for qualifications has resulted in the major focusing of curricula on learning results and has thus changed the character of teaching and learning considerably. In every formal education system, the learning results must therefore clearly and transparently be depicted in the various curricula.
In order to define the most essential learning outcomes, the VET system in Austria has developed its educational standards. These standards include a number of functions, like the improvement of the quality of teaching, the selection of teaching contents, the objective comparison between core competences and the focusing on reaching these competences through teaching [10]. (The term "core competence" is used in the same context as "essential learning results”).

Within the VET system, educational standards are not seen as minimum or maximum standards, they are considered to be average standards. Average standards are those learning outcomes and competences which the learners possess at a certain point of time, in general at the end of their education and training, and which they can exercise with a certain sustainability. Sustainably available competences are therefore those learning outcomes that are the basis for the employability of a graduate and which also serve as a basis for indicating the level of qualification within the National as well as the European Qualifications Framework.

The description of the education standards that have been implemented in the VET colleges in Austria is by Anderson and Kratwohl (2001) by means of a table thatdefines and describes the learning processes in dimensions (Table III) [11].

With the help of this model, each core competence that is achieved within an education can also be described and illustrated by learning outcomes (descriptors) that are 
determined by concrete and cognitive parameters. This system allows teachers and learners, but also tertiary education institutions and prospective employers alike, to see immediately and transparently which competences can be expected from the VET College graduates in Austria. The stakeholders of the Austrian VET colleges have agreed to apply this system of educational and occupational standards to all their curricula and VET programs.

\section{LEARNING-OUTCOME-ORIENTED CURRICULA}

The Austrian Federal Ministry for Education, Arts and Culture has to decree educational standards for different levels of school [12]. It is, however, clear that an educational control instrument, like the standards, only has high relevance if it is agreed upon by the stakeholders and if it is laid down in writing in the appropriate laws and regulations. The Austrian VET colleges and the Ministry of Education have reached a consensus in so far as they have decided to include the educational and occupational standards into their curricula.

Although the education standards have been fully integrated in the curricula, there still remains enough pedagogical freedom within the curriculum to also teach addi- tional or specific topics in the various subjects. This also enables the teachers to emphasise their priorities and to add their special themes to the teaching content. This procedure guarantees that the high acceptance of the curriculum by teachers and learners alike is not negatively influenced by a completely new design. The learning outcomes, which are illustrated as dots in the matrix, shall be considered as learning objectives that complement the core competences. These core competences generally replace the teaching subjects and are implemented in the curricula. If they are, however, interdisciplinary or general teaching objectives, they are implemented in the general teaching objective or in the professional qualification profile of a curriculum. The competence matrix is thus a new instrument that considers the most recent and innovative pedagogic trends, on the one hand, and guarantees, on the other, that the Austrian VET objectives are not completely lost and done away with. The occupational and educational standards which have recently been introduced at the technical colleges in Austria are an excellent example of pedagogic reform and a common European VET attitude at the same time.

TABLE III.

DESCRIPTION OF EDUCATION STANDARDS BY ANDERSON AND KRATWOHL

\begin{tabular}{|l|l|l|l|l|l|l|}
\hline \multirow{2}{*}{$\begin{array}{l}\text { The Knowledge and Skills } \\
\text { Dimension }\end{array}$} & \multicolumn{5}{|c|}{ The Cognitive Process Dimension } \\
\cline { 2 - 6 } & $\begin{array}{c}\mathbf{1} \\
\text { Remember }\end{array}$ & $\begin{array}{c}2 \\
\text { Understand }\end{array}$ & $\begin{array}{c}3 \\
\text { Apply }\end{array}$ & $\begin{array}{c}4 \\
\text { Analyse }\end{array}$ & $\begin{array}{c}5 \\
\text { Evaluate }\end{array}$ & $\begin{array}{c}\mathbf{6} \\
\text { Create }\end{array}$ \\
\hline A: Fachtual Knowledge & & & & & & \\
\hline B:Conceptual Knowledge & & & & & & \\
\hline C: Procedural Knowledge & & & & & & \\
\hline D:Metacognitive Knowledge & & & & & & \\
\hline
\end{tabular}

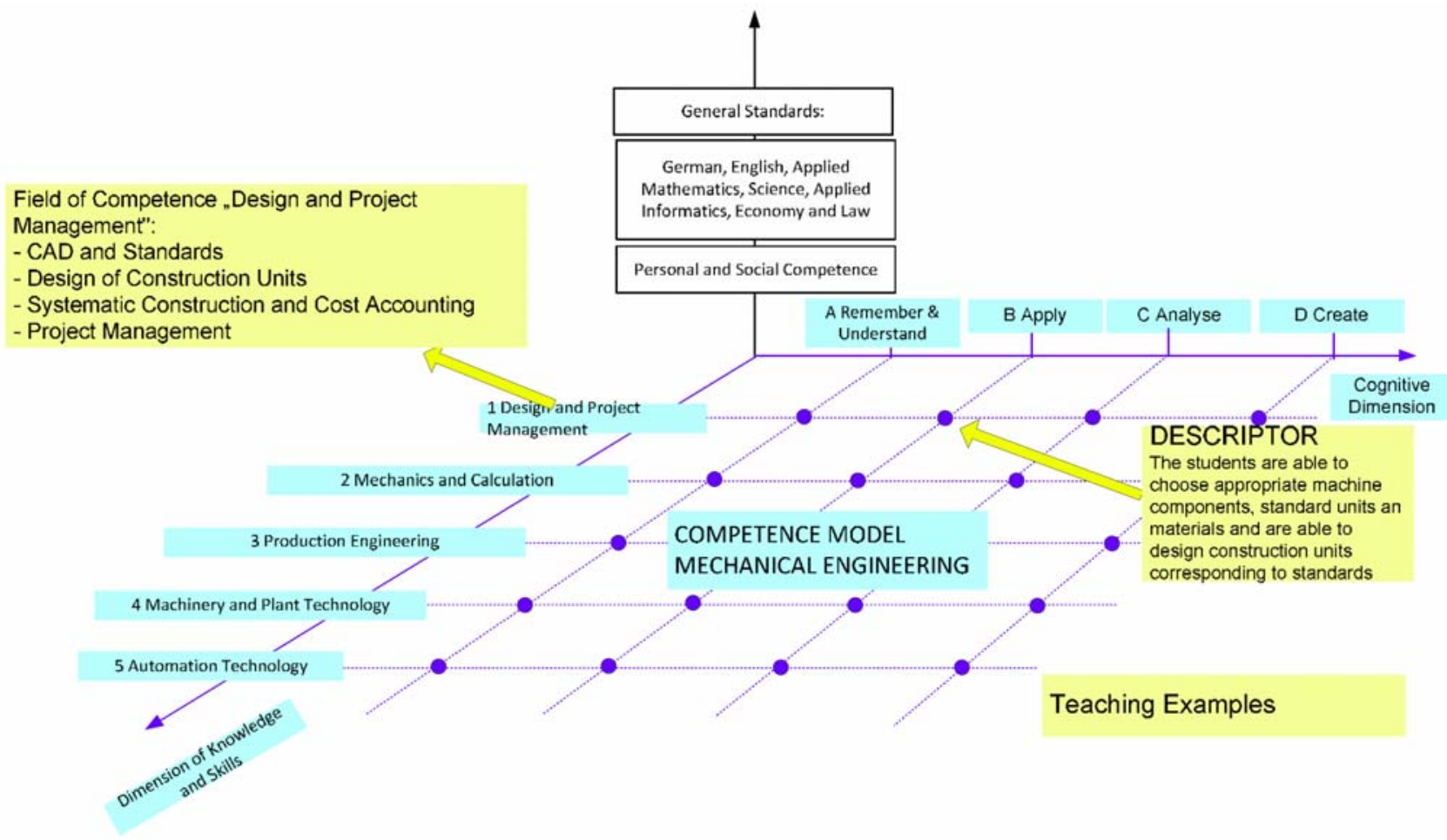

Figure 1. Based on the above-mentioned descriptions, Austria has developed its own model 
TABLE IV.

CURRICUlum OF THE SECONDARY COLLEGE For MECHANICAL ENGINEERING

\section{TIMETABLE}

(Total number of lessons and number of weekly lessons of the different subjects)

\begin{tabular}{|c|c|c|c|c|c|c|c|c|}
\hline & \multirow{3}{*}{ Compulsory Subjects } & \multicolumn{6}{|c|}{ Lessons per week } & \multirow{3}{*}{$\begin{array}{c}\text { Teaching } \\
\text { Assign- } \\
\text { ment- } \\
\text { Group }\end{array}$} \\
\hline & & \multicolumn{5}{|c|}{ Year } & \multirow[t]{2}{*}{ Sum } & \\
\hline & & I. & II. & III. & IV. & $\mathrm{V}$. & & \\
\hline 1. & Religious Instruction & 2 & 2 & 2 & 2 & 2 & 10 & (III) \\
\hline 2. & German & 3 & 2 & 2 & 2 & 2 & 11 & (I) \\
\hline 3. & English & 2 & 2 & 2 & 2 & 2 & 10 & (I) \\
\hline & $\begin{array}{l}\text { Geography, History, Political Educa- } \\
\text { tion }^{1}\end{array}$ & 2 & 2 & 2 & 2 & - & 8 & III \\
\hline 5. & Economy and Law & - & - & - & 3 & 2 & 5 & II/III \\
\hline 6. & Physical Education & 2 & 2 & 2 & 1 & 1 & 8 & IVa \\
\hline 7. & Applied Mathematics & 4 & 2 & 2 & 2 & 3 & 13 & I \\
\hline & Science & 3 & 2 & 2 & 2 & - & 9 & II \\
\hline 9. & Applied Informatics & 2 & 2 & - & - & - & 4 & I \\
\hline 10. & Design and Project management ${ }^{1} 1$ & $4(3)$ & $7(4)$ & $6(3)$ & $4(4)$ & $4(4)$ & 25 & I \\
\hline 11. & Mechanics and Calculation & 2 & 3 & 3 & 2 & 2 & 12 & I \\
\hline 12. & Production Engineering ${ }^{1}$ & 2 & 2 & 2 & 3 & 2 & 11 & I \\
\hline 13. & Machinery and Plant Technology & - & - & 2 & 4 & 5 & 11 & I \\
\hline 14. & Automation Technology & - & - & 3 & 3 & 5 & 11 & I \\
\hline 15. & Laboratory & - & - & - & 3 & 3 & 6 & I \\
\hline 16. & Workshop $^{1}$ & 7 & 8 & 8 & 3 & 3 & 29 & III/IV \\
\hline 17. & Social and Personal Competence & $1(1)$ & $1(1)$ & - & - & - & 2 & III \\
\hline Tota & Number of lessons per week & 36 & 37 & 38 & 38 & 36 & 185 & \\
\hline
\end{tabular}

\section{DESIGN and PROJECT MANAGEMENT}

Competence Area „Construction Units, Standards and CAD“

\section{Training and Teaching Aims:}

The student will be able to:

- understand the economic consequences of manufacturing information;

- choose machine elements, standardised parts and materials, to dimension components standard-compliant, also with specific calculation software;

- assess constructions with regard to their function and manufacturability;

- design components compliant with given material, function, manufacturing, and assembling standards.

\section{Teaching matter:}

$2^{\text {nd }}$ year:

Surfaces, tolerances, fittings;

Selection of, standard-compliant representation and calculation of separable joints and non-separable joints as well as of safety elements;

Parts lists.

$3^{\text {rd }}$ year:

Selection of, standard-compliant representation and calculation of axles, shafts, bearings,

shaft-hub-connections, spring elements, gear wheels, transmissions, couplings, pipelines and fittings.

$4^{\text {th }}$ and $5^{\text {th }}$ years:

Calculation and design of complex components and systems, as well as projects to complement and to deepen the knowledge and skills from the compulsory subjects. 
In general, the educational standards now implemented at the Austrian VET Colleges have also been included in the various curricula and have also been promulgated as legal regulations accordingly. In spite of this integration process, certain structural elements of the curriculum, as for example the general educational goals, the teaching objectives, the subject matter, etc., remain largely unchanged. This guarantees that any positive understanding and any acceptance of the curriculum is not affected by a completely new design.

In the above graphic illustration of the matrix, the grid points representing the learning outcomes become learning objectives and consequently core competences for the students. These competences replace the specific teaching subjects and are directly entered into the curricula, or, if they are general or broader educational objectives, into the general educational goals or into the specific qualification profile of a curriculum.

One such example of the procedure described above can be seen in the following excerpt from the new curriculum of the Higher Technical College for Mechanical Engineering (Table IV.).

\section{COMPETENCE-ORIENTED TEACHING, EXTERnAL VS. INTERNAL VIEW}

What has been laid out so far, shows the changes that have been imposed on the Austrian Technical Colleges from outside, namely from the controlling bodies and institutions, as well as from the requirements and necessities expressed by the labour market, the curricula and the classification within the European Qualifications Framework (EQF). Thus, the current developments may be described as changes within the education system that have, however, been initiated by external effects.

Although external input measures are tremendously important for any educational reform, the internal acceptance and understanding within the community of those members of staff involved, namely the principals and the teachers, is as important. The consequences of all the new measures undertaken must first and foremost show in a changed behaviour in the classroom, in the teaching and in the learning situation. The expected methodological and didactic changes should therefore materialise in the new teaching concepts as competence-oriented teaching and learning on the one hand, and as individualisation on the other hand.

The first steps have already been undertaken in both of the above-mentioned areas by raising the teachers' awareness for the new concepts and by launching teacher training campaigns in this respect. Within the VET sector, the acceptance of the approach of competence orientation has, however, been met with more enthusiasm than within the general education sector. The Austrian Technical Colleges have committed themselves to a high standard of professionalism and have thus willingly adopted the concept of competence orientation into their curricula, because they want to produce graduates that are compatible with the needs of the Austrian economy and the Austrian industry, as well as with the requirements of the job market.

Competence-oriented teaching has its roots in traditional learning theories like behaviourism, cognitivism and constructivism, however, based on these ideas, new approaches will have to be developed in order to achieve the modified goal-orientation, which presupposes a high degree of independence and self-reliance. What also has to be considered within this new concept of competenceoriented teaching are the recognition and the considering of individual learning interests, learning styles, but also personal as well as professional learning objectives.

This actually means a turning away from traditional subject-oriented teaching, because such an education very often lacks real problem- or project-based teaching and learning. Consequently, such teaching has also led to a certain frustration among students, because they could not apply the theory that they had learned in complex classroom-situations to their professional reality. It can thus be concluded that pure subject-matter teaching does not prepare the learners for the real conditions and requirements of the world of work, because our new occupational world has changed tremendously.

In the sense of competence-oriented teaching, the learning process must in future be understood as an active, constructive and fruitful process that can be compared with real-life working situations and also simulates these working situations by fostering an orientation towards real action in the sense of applying, analysing and developing. At the Austrian Technical Colleges, this aim will in future be achieved through education standards and competence-based curricula.

\section{REFERENCES}

[1] Statistiken im Bereich Schule und Erwachsenenbildung in Österreich, Zahlenspiegel 2009, Bundesministerium für Unterricht, Kunst und Kultur

[2] § 72 Schulorganisationsgesetz (SchOG), BGBl Nr. 242/1962 i.d.g.F, Besondere Bestimmungen - Höhere technische und gewerblichen Lehranstalten

[3] Schneeberger, Arthur et al., IBW Schriftenreihe 138, Mittelfristige Perspektiven der HTL , 2005, Seite 38

[4] Schneeberger, ebenda, Seite 162

[5] Statistik Austria, Österreichische Hochschulstatistik 1999/2000, Wien 2001, Seite 270.

[6] Bundesministerium für Wissenschaft und Forschung, Statistisches Taschenbuch 2007, Wien 2007, Seite 82

[7] Bundesministerium für Wissenschaft und Forschung, ebenda, Seite 77

[8] Schneeberger Arthur, ebenda, Seite $55 \mathrm{ff}$

[9] Empfehlung des Europäischen Parlamentes und des Rates zur Einrichtung des Europäischen Qualifikationsrahmens für lebenslanges Lernen , 2008/C111/01, http://ec.europa.eu/education/ policies/educ/eqf/rec08 de.pdf

[10] Fritz Ursula, Eduard Staudecker in Bildungsstandards in der Berufsbildung, Manz 2010, Seite 17

[11] Anderson, L. und Kratwohl, D., in A Taxonomy of Learning, Teaching and Assessing, 2001

[12] § 17 Abs 1a SchUG

\section{AUTHORS}

W. Pachatz is Deputy Head of the Department for Technical Schools and Colleges in the Federal Ministry for Education, the Arts and Culture in Vienna (e-mail: Wolfgang.pachatz@bmukk.gv.at) and has been involved in the development of educational standards and standardbased curricula at the Austrian HTL since 2004. His main fields of interest are quality management, curriculum design, comparison of education systems and international classification of educational programmes. He has worked at HTL in Vienna and Lower Austria and in teacher training institutions. His current focus lies on the 
PAPER

EDUCATION STANDARDS AND COMPETENCE-ORIENTED CURRICULA - THE AUSTRIAN TECHNICAL COLLEGES TAKE A

NEW APPROACH TO EXCELLENCE

implementation of new curricula and the ISCED and EQF processes.

A. Zafoschnig is a Chief Inspector for VET Colleges in Carinthia (e-mail: axel.zafoschnig@lsr-ktn.gv.at, Landesschulrat für Kärnten) and has specialised in learning management, teacher training and curriculum design at the Austrian HTL. His main fields of interest are engineering education, comparison of education systems, school development and the internationalisation of the
Technical Colleges. He has worked at HTL in Carinthia and at teacher training institutions in both Austria and the UK. His current focus lies on implementing the educational reform concept in Carinthia, on networking on behalf of IGIP, and on representing the Austrian Inspection System on behalf of the Ministry of Education on an international level.

Received 19 September 2011. Published as resubmitted by the authors 26 September 2011. 